\title{
HIGHLIGHTS
}

HIGHLIGHTS ADVISORS

\section{KONRAD BASLER}

UNIVERSITY OF ZURICH,

SWITZERLAND

\section{WENDY BICKMORE}

MRC HUMAN GENETICS UNIT, UK

\section{PEER BORK}

EMBL, GERMANY

\section{STEVE BROWN}

MRC MAMMALIAN GENETICS UNIT, UK

\section{SEAN B. CARROLL}

UNIVERSITY OF WISCONSIN, USA

\section{JANAN EPPIG}

THE JACKSON LABORATORY, USA

\section{ADAM EYRE-WALKER}

UNIVERSITY OF SUSSEX, UK

\section{CLAIRE M. FRASER}

THE INSTITUTE FOR GENOMIC RESEARCH, USA

\section{YUJI KOHARA}

NATIONAL INSTITUTE OF GENETICS RESEARCH, JAPAN

\section{PETER KOOPMAN}

UNIVERSITY OF QUEENSLAND, AUSTRALIA

\section{LEONID KRUGLYAK}

FRED HUTCHINSON CANCER RESEARCH CENTER, USA

ROB MARTIENSSEN

COLD SPRING HARBOR LABORATORY, USA

\section{GAIL MARTIN}

UC SAN FRANCISCO, USA

\section{BARBARA MEYER}

UC BERKELEY, USA

LAP-CHEE TSUI

THE HOSPITAL FOR SICK CHILDREN, CANADA

\section{KEN WOLFE}

UNIVERSITY OF DUBLIN, IRELAND

\section{RICHARD YOUNG}

MASSACHUSETTS INSTITUTE OF TECHNOLOGY, USA

\section{DEVELOPMENTAL BIOLOGY}

\section{Two-step regulation of asymmetry}

Mr Spock's is on the right, and Dr Who has two. These examples of abnormal heart development reflect disturbances in left-right asymmetry, which is established very early in embryogenesis. A collection of genes involved in setting up left-right asymmetry has been discovered, and the broad outlines of a pathway leading to left-right asymmetric organogenesis are emerging. But there are many gaps in the pathway, one of which is the subject of a recent paper from Hiroshi Hamada's group. Their analysis of an asymmetrically expressed transcription factor, Pitx2, also suggests a model that might be generally relevant to developmental regulation.

Pitx2 is expressed on the left side of the early mouse embryo, and is required for the asymmetric development of internal organs, such as the heart. The timing of Pitx 2 expression suggests that it acts downstream of two other genes - nodal and lefty 2 - both of which encode members of the TGF- $\beta$ family of signalling molecules, and are important in establishing left-right asymmetry.

The aim of this study was to figure out how Pitx 2 is regulated in the pathway that leads to left-right asymmetry. To do this, transgenic mouse constructs that carried genomic regions encompassing the Pitx 2 gene were linked to a $l a c Z$ reporter. The authors found a $0.6-\mathrm{kb}$ left-side-specific enhancer (ASE) within intron 5 of Pitx2, which is necessary and sufficient for the left-side expression of Pitx2.
A detailed analysis of the ASE revealed two distinct regulatory sequences. Initially, binding sites for the FAST transcription factor were identified, and were shown to be essential for the initiation of Pitx2 asymmetric expression. Because FAST is activated by nodal signalling, these results imply that Pitx2 is a direct target of nodal. However, the FAST binding sites alone cannot sustain Pitx2 expression, which persists after nodal expression has ceased. Further dissection of the ASE revealed a second transcription-factor binding site for $\mathrm{Nkx} 2-5$. This site is required only for the later asymmetric expression of Pitx2, although Nkx2-5 itself is not asymmetrically expressed and cannot initiate asymmetric expression.
The authors propose a model to account for Pitx 2 regulation, in which the Pitx 2 gene is activated and made accessible to further transcription factors (such as Nkx2-5) by nodal signalling. Although Nkx2-5 is present symmetrically, it maintains and shapes Pitx 2 expression only on the left because previous exposure of Pitx 2 to nodal signalling was restricted to this side. This two-step model of regulation is a satisfying example of how the expression patterns of distinct regulators can be integrated to provide a specific regulatory output, and will inform studies of other aspects of developmental regulation.

Mark Patterson

(0) References and links ORIGINAL RESEARCH PAPER Shiratori, $H$. et al. Two-step regulation of left-right asymmetric expression of Pitx2: initiation by nodal signaling and maintenance by Nkx2. Mol. Cell 7, 137-149 (2001)

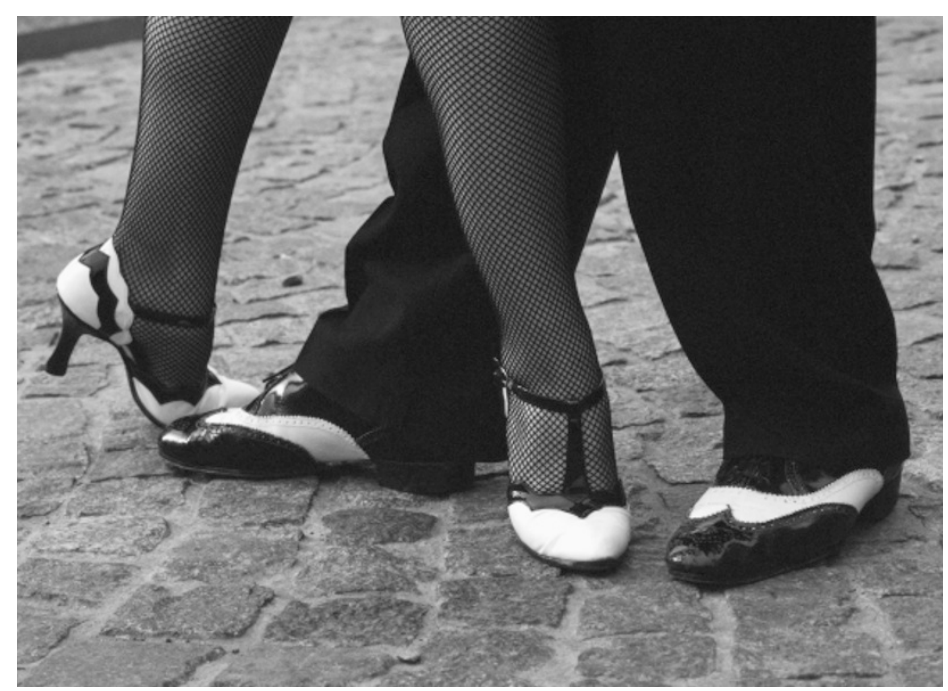

